\title{
The Kāmasiddhistuti of King Vatsarāja
}

\author{
Diwakar Acharya
}

This essay concerns a püjāstuti ${ }^{1}$ that guides its reciter through the mental or actual worship of the goddess Nityā. The text is composed in the first person but the author does not name himself in the text. The text is named Vāmakeśvaristuti and attributed to Mahārājādhirāja Vidyādharacakravartin Vatsarāja in the colophon of the sole palm-leaf manuscript of the text available to me. However, the last verse of the text calls it Kāmeśvarīstuti and describes it using two adjectives, kāmasiddhi and atimañgalakāmadhenu. It is not unnatural, I think, to name this stuti using its first adjective. ${ }^{2}$

The manuscript containing this stuti text is preserved in the National Archives, Kathmandu. It bears accession number 1-1077 and can be found microfilmed under NGM PP reel number A 39/15. The same manuscript also contains a paddhati text called Aśeșakulavallari that dwells on the worship of the goddess Tripurā, but this text remains incomplete as the folios following the sixteenth are absent. Our text begins on the verso of the first folio and ends in the third line of the recto of the fourth, with a colophon and a decorative symbol. The other text immediately follows in the same hand with a salutation to the goddess Tripurā. The manuscript is written in a variety of North Indian script close to Newari with frequent use of prșthamātrās. It is possible that this manuscript was copied by an immigrant or pilgrim in Kathmandu valley. It measures $33 \times 4.5 \mathrm{~cm}$ and has a binding hole to the left of the centre. It bears foliation in numerals in the left margin and in numbers in the right margin of verso folios. The text in the manuscript is dotted with scribal errors, but no secunda manus corrections are seen. On palaeographical grounds I place the manuscript in the late fourteenth century.

This manuscript contains 46 verses of the stuti and one more verse (numbered here as $38 \mathrm{a}$ ) can be retrieved from a citation. ${ }^{3}$ A little less than the half of the stuti covering the first 21 verses is in Anușțubh metre and the rest in

1 A number of püjāstutis of the Tripurā traditon can be found in the appendix section of Dwivedi 1985. Aghoraśiva's Pañcāvaranastava, published from Pondicherry (see Goodall et al. 2005), is a good example of a Siddhānta Śaiva püjāstuti.

2 See footnote 32 for further discussion on the name, extent and circulation of the text.

3 See foonote 32 for details. 
Vasantatilakā. Verses $3^{1}$ and $3^{2}$ form a yugalaka as the finite verb comes only in the second verse. The author plays now and again with syllabic rhyming (anuprāsa), and his language is beautiful, though sometimes elliptical.

The stuti opens with a pair of verses invoking Paramaśiva and Nityā Śakti. These verses already tell us of the poet's understanding of the nature of Nityā and inseparability of Paramaśiva and Śakti, a point highlighted in the second half of the text, particularly verses $31-32$ and 42 . In verse 3 the poet states that he approaches the temple of Mṛạāni from the west gate (paścimadvāra). ${ }^{4}$ The next two verses invoke Ganeśa and Kșetreśa. The latter, who has the form of Bhairava, can be identified as Bațuka. Ganeśa and Bațuka together are identified as the goddess's sons in Sākta systems and serve as her doorkeepers. ${ }^{5}$ To our surprise, verse 6 invokes the Vaișnava doorkeepers Śankkhanidhi and Padmanidhi, who bear the Vaișnava emblems of the conch and lotus on their heads. ${ }^{6}$ Verses $7-9$ invoke respectively three goddesses: Padmā, a Vaișnava version of Durgā carrying a conch and discus, and Bhāratī. Verses 10 and 11 invoke Manobhava, namely, the Indian love-god Kāmadeva, and describe him as the

4 This should be the intended meaning, because one is supposed to enter a temple from the western or southern gate facing east or north. Therefore, many of the early Śaiva-Śākta temples, even though they face east, have an older western or southern entry. For more discussions, see Goodall et al. 2005, 103-107 and Goodall et al. 2015, 366 (Niśvāsa, Uttarasūtra 3:8 and annotation thereon). Another possible interpretation of paścimadvāra is "the last door to resort to." Perhaps, the poet is punning.

5 For Gaṇeśa and Bațuka as the Goddess' sons, See, e.g., Jayaratha on Tantrāloka 1.6b.

6 Śạkhanidhi and Padmanidhi have strong associations with the cult of Yakșas. In the Meghadūta, Kālidāsa's Yakșa tells the cloud-messenger that the marks of conch (śamkha) and lotus ( padma) are painted on the sides of the gate of his house in the city of Alakā, as he provides a number of clues for the identification of his house. In the form of emblems as well as human forms, Śạkhanidhi and Padmanidhi are depicted in the Ajanțā caves and are associated with Yakșa deities (cf. Bautze-Picron 2002, 225-231). Besides, the Buddhist Vasudhārā Dhāraṇi enjoins worship Śan̉khanidhāna and Padmanidhāna with the goddess Vasudhārā encircled by a group of eight unspecified Yakșinīs. Some other texts name Śaṃkhanidhi and Padmanidhi as male consorts of Vasudhārā and Vasumatī, respectively. Anyway, these two are adopted by the Vaiṣnavas as doorkeepers or attendants of Viṣnu along with the other pairs of Jaya and Vijaya, Candia and Pracanda, Nanda and Sunanda. They also feature in some comparatively late Tantric texts of other traditions, particularly those from the south. They are listed also among the twelve Vaiṣnava nidhis found in some Puranic and Vaiṣnava texts. Professor Dominic Goodall kindly informs me (personal communication of November 20, 2019) that what is now called the Kailāsanātha temple in Kancheepuram seems to have Śankkhanidhi and Padmanidhi framing the doorway. According to him, that temple now has an eastern entrance to the enclosure, but there is an older western entry, now blocked up.

For an example of images of Śaṃkhanidhi and Padmanidhi from Anurādhapur, Sri Lanka, See Paranavitana 1955 . 
beloved husband of Rati and Priti. ${ }^{7}$ Here we are told that the love-god forms the circular base of the Śrīcakra, the maṇala of the goddess Nityā Sundarī. With these verses the text enters the process of installation of various deities in the Srīcakra. It does not specify where these deities are installed, but from the order of verses we know that we are starting from the periphery and moving towards the centre. Verses 12-14 respectively praise eight siddhis, beginning with Aṇimā (in personified forms), eight mother-goddesses, and the deities of ten gestures of the goddess. ${ }^{8}$ Verses 15 and 16 venerate sixteen goddesses of attraction (ākarșaṇa) and eight powers of the bodiless love-god (anangaśakti), respectively, all in personified forms. ${ }^{9}$ We know from the Vāmakeśvaratantra and other Tripurā texts that these are installed on the petals of the sixteen- and eight-petalled lotuses. The next four verses, $17-20$, respectively praise the set of fourteen goddesses/powers (śaktis) headed by Sarvasaṃkṣobhaṇī, ${ }^{10}$ ten Kula

7 For Rati and Prīti as Kāmadeva's wives, see, e.g. Brahmāṇ̣̂a Purāna III.44.33. A Śunga period teracotta plaque of Kāmadeva with Rati and Prīti is also preserved in the Mathura Musuem (accession no. 34-2552).

8 It is possible that these three sets of deities are installed on the three lines forming the outermost retinue of the rectangular boundary. The Vāmakeśvaratantra, also known as Nityāșodaśikärnava, enjoins installing the eight mother-goddesses as well as the eight siddhis in the four directions and four sub-directions, and does not instruct one to worship the goddesses of the gestures. Bhāskararāya (p. 99), however, mentions that according to some other system the outermost boundary is made of three lines and these three sets of goddesses are installed there. According to its commentators, the Vāmakeśvaratantra teaches that one should build the boundary with only two lines. Although the Vāmakeśvaratantra does not assign a place for the gestures $(m u d r a \overline{)})$ in the mandala, it does describe them and asks the worshipper to use them during the worship. As found in the third chapter

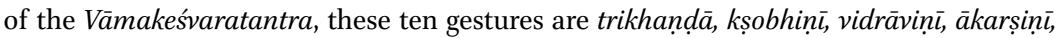
āveśakarī, unmādinī, mahāinkuśä, khecarī, büja, and yoni.

As listed in many texts, including the Niśvāsaguhya (7.204-205), the eight siddhis are aṇimā, laghimā, mahimā, issitva, vaśitva, prāpti, prākāmya, and yatrakāmāvasāyitā. The Vāmakeśvaratantra (1.153-155) makes them ten by adding two more, bhukti and icchā, and prescribes worshipping them in ten directions. According to the latter (1.156-157), the eight mother-goddesses are Brahmāṇī, Māheśí, Kaumārī, Vaiṣnavī, Vārāhī, Indrāṇī, Cāmuṇụā, and Mahālakșmī.

9 These are not individually named in this text, but, as listed in the Vāmakeśvaratantra, the first set is made of Kāmākarṣiṇī, Budhyākarṣiṇī, Ahaṃkāāākarșiṇī, Śabdākarșinīi, Sparśākarṣiṇī, Rūpākarṣiṇī, Rasākarṣiṇī, Gandhākarṣiṇī, Cittākarṣiṇī, Dhairyākarṣiṇī, Smṛtyākarṣiṇī, Nāmākarṣiṇī, Bījākarșiṇī, Ātmākarṣiṇī, Amṛtākarṣiṇī, and Śarīrākarṣiṇī (cf. 1.158161), and the second set is made of Anangakusumā, Anangamekhalā, Ananggamadanā, Madanāturā, Anaṅgarekhā, Anaṅgaveginī, Anaṅgāṅkuśā, and Anaṅgamālinī (cf. 1.163164).

10 We know only the name of the first from this text but the rest can be known from the Vāmakeśvaratantra (1.165-168). They are: Sarvavidrāviṇī, Sarvākarṣiṇī, Sarvāhlādinī, Sarvasaṃmohinī, Sarvastambhanī, Sarvajambhanī, Sarvatovaśinī, Sarvarañjanī, Sarvon- 
goddesses (kuleśvarī) headed by Sarvasiddhipradā,11 ten goddesses headed by Sarvajñā, ${ }^{12}$ and eight goddesses of speech, headed by Vaśinī. ${ }^{13}$ They are stationed in the four consecutive retinues of fourteen, ten, another ten, and eight triangles. All deities in a group (see verses 12-20) are visualised in the same way; for example, all mother-goddesses (mātr) have the same appearance. ${ }^{14}$ Verse 21 invokes and asks the deities of four weapons of the goddess for their permission. It is known from other sources that they are placed around the central triangle (cf., e.g., Vāmakeśvaratantra 1.179-180). The next three verses, 22-24, praise Kāmeśvarī, Vajreśvarī, and Bhagamālinī, and urge them to fulfill the reciter's desires. Unlike previous ones, these verses also name the three corners of the central triangle as the homes of these goddesses. Verse 25 is in praise of Nityā Sundarī, the goddess in the centre. From here onward, until the second to last verse (45), the poet praises Nityā in various ways. He first invokes the goddess as Nityā (verse 25) and later as Śrīsundarī (verse 30), and describes her as "the felicitous banner of the Love-god." Verses $25^{-28}$ describe the beauty of the goddess, and verses 29-45, with the exception of verse 33 (which describes the Śricakra made of 43 triangles as her abode), exalt her in various ways, identifying her as the ultimate reality of the external as well as internal worlds. She is described as the primordial light ( $\bar{a} d y a m a h a s)$ and paramārthavidy $\bar{a}$, which can be interpreted as the highest mantra, the mantra leading to the highest, or the ultimate gnosis. The last verse is a fine eulogy of the stuti itself, describing its reward and thus encouraging people to recite it.

It has been already pointed out by Sanderson and also Golovkova that the mature cult of Tripurasundarī developed against the backdrop of the nitya cult, evidence for which is available in the Nitya kaulatantra and the Siddhakhanda of the Manthannabhairavatantra. In those texts Tripurasundarī is accompa-

mādinī, Sarvārthasādhanī, Sarvasampattipūraṇī, Sarvamantramayī, and Sarvadvandvakṣayamkarī.

11 Again, the list can be completed with the help of the Vāmakeśvaratantra, but these goddesses are here simply called śaktis. The other nine following Sarvasiddhipradā are: Sarvasampatpradā, Sarvapriyaṃkarī, Sarvamaṅgalakārinī, Sarvakāmapradā, Sarvaduḥkhavimocinī, Sarvamṛtyupraśaman̄̄, Sarvavighnanivāriṇī, Sarvāngasundarī, and Sarvasaubhāgyadāyinī (cf. 1.169-171).

12 Sarvajñā is followed by Sarvaśakti, Sarvaiśvaryapradāyinī, Sarvajñānamayī, Sarvavyādhivināšinī, Sarvādhārasvarūpā, Sarvapāpaharā, Sarvānandamaȳi, Sarvarakṣāsvarūpiṇī, and Sarvepsitaphalapradā (cf. Vāmakeśvaratantra 1.173-175).

13 The names of these eight can be retrieved from the mantroddhāra section of the Vāmakeśvaratantra (cf. 1.77-80). They are Vaśinī, Kāmeśvarī, Modinī, Vimalā, Aruṇā, Jayinī, Sarveśvarī, and Kaulinī.

14 Neither the Vāmakeśvaratantra nor any of the paddhatis of that tradition give visualisations of these deities. 
nied by a retinue of eleven and nine nityās, respectively, and worshipped with Kāmadeva. ${ }^{15}$ Our text identifies Kāmadeva as the husband of Rati and Prīti, places him on the base of the Śrīcakra (cf. verses 10-11), and installs Nityā Sundari at the altar of worship in the centre of the mandala without a consort, independent and supreme. However, in verses $31-32$ she is described as devamahiși, although it is said that their body is one and undifferentiated. In verse 2 the poet names the goddess Nityā and invokes her as the Śakti of Paramaśiva possessing all powers and carrying out the five tasks (pañcakrtya) for him. In verse 34 the poet invokes her as Maheśvarī but states that some royal people in this world call her Lakșmī and Parā Prakṛti. In verse 40 she is described as Atibhavā, highlighting her transcendent nature, and in verse 42 she is invoked again as Gaurī. It is thus clear that the poet of our text is a Śaiva devotee of goddess Nityā. It is important to note that in the system known to our poet there is only one Nityā, simply called Sundarī, and that the Śrīcakra is also already known. Our poet appears unaware of the sixteen nityās, who are worshipped in the tradition of the Vàmakeśvaratantra. It thus appears that the tradition this stuti text represents is different from both the cult of nityās and that of Tripurā.

The inclusion of Śańkhanidhi and Padmanidhi (verse 6), Padmā (verse 7), and the Vaiṣnava Durgā (verse 8) suggests that the goddess Nityā is somehow linked to the Vaiṣnava tradition as well. In fact, in verse 34 the poet mentions that some people call her Lakșmī and Parā Prakṛti, but we are not aware of survival of any Vaiṣnava paddhati of Nityā.

Now I come to the issue of the poet's identity. The fact that he is a king and was perhaps somewhat distressed at the time of composition of the stuti can be known from the text itself (cf. verse 40). Furthermore, in the colophon the text is attributed to Mahārājādhirāja Vidyādharacakravarti Vatsarāja. ${ }^{16}$ Apparently, the first epithet is royal — he is the king of great kings — while the second is mantric: he is sovereign among the vidyädharas, who are supposed to possess esoteric mantric knowledge and due to this have supernatural powers. Vatsarāja is his personal name. The most famous Vatsarāja, the mythical king of Ujjayinī, does not fit the context. Another is King Vatsarāja of the GurjaraPratihāra dynasty (c. 775-805 CE), the father of Mahārājādhirāja Nāgabhața II $\left(805^{-833 C E}\right)$. Vatsarāja is always called paramamāheśvara, but in the Pratāpagaḍh Stone Inscription of Mahendrapāla II (dated Year $1003=946 \mathrm{CE}$ ),

15 cf. Sanderson 2009, 47-49; Golovkova 2012, 816-817.

16 It is interesting to note that a fifteenth-century inscription from Vijayanagara remembers a king called Vatsarāja blessed by Tripurāmbā. As Sinopoli (2010, 22) cites, “'As Vani blesses king Bhoka, Tripuramba king Vatsaraja, and Kali king Vikramarka, so does Pampa now bless Devaraya' (trans. Rajasekhara 1992: 27)." 
Nāgabhața II is called paramabhagavatïbhakta. ${ }^{17}$ It may be a coincidence, but the latter's mother is named Sundarī. In any case, this Vatsarāja could be our poet. ${ }^{18}$ Our text represents an archaic tradition that does not even know the name Tripurasundarī, and thus this date in the early-ninth century CE fits it well.

\section{Text and Translation}

${ }^{19}$ nị̂simmānandayā devyā nityam samarasātmanaḥ | paramasya śivasyāhaṃ śraye śrīpādukādvayam $\|1\|$

a. niḥsīmāo ${ }^{\circ}$ em.; niḥsāāmā ${ }^{\circ}$ Ms. b. ${ }^{\circ}$ rasātmanaḥ] em.; ${ }^{\circ}$ rasānmanah Ms.

I resort to the glorious sandals of Paramaśiva (Śiva in the Ultimate state), who is eternally in equilibrial union with the Goddess characterised by boundless bliss (niḥsimānanda). ${ }^{20}$

sarvānugrāhinīm nityām sarvamañgalamātaram | sarvaśaktị̣ bhaje śaktim pañcakrtyakarị̣ prabhoh ||2\|

a. sarvānugrāhiṇị̣̄] em.; sarvān grāhinīi Ms. d. ${ }^{\circ}$ karīṃ] em.; ${ }^{\circ}$ karī Ms.

I revere the Nityā Śakti of the Lord, i.e. Paramaśiva. She possesses all powers and carries out the five tasks [for him]. ${ }^{21}$ She bestows grace upon all, is eternal, and is the motherly origin of all good.

17 cf. Sircar 1983, 251.

18 There is another poet of the same name who flourished in the second half of the twelfth and the first quarter of the thirteenth century CE (cf. Dalal 1918, vi-vii), but he is a minister, not a king. He served the Kālañjara King Paramardideva and wrote some dramatic pieces. Six of such pieces have been published in one volume under the title Rüpakașațkam (see Dalal 1918). He does not mention Nityā, Sundarī, or Tripurasundarī in his dramas.

19 The manuscript begins with an invocation, \|om namo ganapataye $\|$, preceded by a siddhi sign. I do not think that this invocation is part of the text.

20 The manuscript reads nihśámānanda- and I have emended it to nihsīmānanda. I have found this compound used at least in one more text, the Adhikaranasārāvalī of Vedāntadeśika.

21 The five tasks of Śiva include punishment (nigraha) and grace (anugraha), besides creation, maintenance, and destruction. 
pālitam bahir indrādyaih paramaiśvaryaśobhitam |

prapadye paścimadvāram mrệanyā mandiram mahat $\|3\|$

b. paramaiśvarya ${ }^{\circ 22}$ ] em.; parameśvarya ${ }^{\circ}$ Ms.

I approach the great temple of goddess Mṛdānī that opens to the west. It is guarded outside by Indra and the other [gods who guard the directions], and shines beautifully with utmost richness.

pāsāànuśaphalāmbhojaị pāṇipadmam tu maṇditam | bālaṃ vighnacchidam vande gajavaktram gaṇeśvaram $\|4\|$

a. ${ }^{\circ}$ phalāṃbhojaih] conj.; ${ }^{\circ}$ phalāṃbhoja Ms. b. pāṇipadmaṃ tu maṇ̣itam] conj.; pāṇipādan tu nanditam Ms. c. bālaṃ] conj.; bāraṃ Ms.

I venerate the young elephant-faced master of Śiva's ganas, the destroyer of obstacles. His lotus-hands ${ }^{23}$ are decorated with a noose, goad, fruit, and lotus.

kapālaśūlau bibhrāṇaṃ krpāluṃ kṛ̣navigraham |

trīkṣaṇaṃ tīkṣnam arcāmi kṣetreśạ̣ kșatavidvișam $\|5\|$

a. śūlau bibhrāṇaṃ] em.; `śūlo bibhrāṇa Ms. b. kṛpāluṃ] em.; kṛpālu Ms. b. kṣetreśam kșata $^{\circ}$ em.; hyetreśam hyata ${ }^{\circ}$ Ms.

I worship the three-eyed sharp-natured Kșetreśa. His body is black, he has destroyed his adversaries, he carries a skull-bowl and a spear, [but] he is compassionate. ${ }^{24}$

varābhayadharau dhïrau viśvasaṃkalpakalpakau| śan்hapadmāsanagatau śaṃkhapadmanidhī śraye $\|6\|$

I resort to Śankkhanidhi and Padmanidhi, who who sit upon a conch and lotus [respectively] as their seats. They are patient, bear the gestures of generosity and protection in their hands, and bring about everyone's dreams.

22 pāramaiśvarya ${ }^{\circ}$ is equally possible.

23 Finding the manuscript reading pānipādan tu nanditam problematic, I have conjectured pānipadmam tu maṇditam.

24 This description reveals that Kṣetreśa has the form of Bhairava. I assume that he is Bațukabhairava on the basis of his Bhairava-like appearance and companionship with Ganeśa. 
padmadvayavarābhītibhāsvatpāṇicatuștayam | padmavallị̣ bhaje padmām padmākșịn padmavāsinīm ||7\|

c. ${ }^{\circ}$ vallīm bhaje padmāṃ] em.; ${ }^{\circ}$ vallī bhaje padmā Ms. d. padmākșīm ${ }^{25}$ ] em.; padmāhyā Ms.

I honour Padmā, [beautiful and tender like] a lotus plant. Her eyes are lotus-like and she dwells in a bed of lotuses. Her four arms look splendid with two lotuses [in two hands] and the gestures of grace and safety [in two others].

śañkhacakrānikitakarā kumārī kuṭilālakā | mrgendravāhanā devī durgā durgāṇi hantu me $\|8\|$

b. kuțilāo] em.; kuḍhilāo Ms.

May the virgin goddess Durgā annihilate my hardships (durgāni), I pray. Her hands are marked by the conch and discus. She has curly locks and rides [a lion,] the king of wild animals.

akṣasrakpustakadharā pūrnacandrāmaladyutih |

viśvavidyāmayì devī bhāratī bhāsatāṃ mayi $\|9\|$

a. akșa ${ }^{\circ}$ em.; ahya ${ }^{\circ}$ Ms. d. bhāratī] em.; bhāratā Ms.

May goddess Bhāratī shine upon me, I pray. She carries a rosary and a book in her hands, she has the stainless complexion of the full moon, and she embodies the entirety of knowledge.

palāśapațalacchāyaṃ raman̄ìam ratipriyam |

pușpeșucāpam puṣpeșumantam vande manobhavam $\|10\|$

prapadye prïtidayitam pūrnenendum iva veștitam |

āśrayam śakticakrasya śrīcakrāñncitaye śriye $\|11\|$

1oc. pușpeșu ${ }^{\circ}$ conj.; puṇdeșu ${ }^{\circ}$ Ms. $\quad{ }^{\circ}{ }^{\circ}$ mantam] em.; ${ }^{\circ}$ mattam Ms. 11b. pūrṇendum iva veștitam] em.; pūṇṇendur i veștitam Ms.

25 padmākșām is possible, but as I have observed confusion between the mātrās of $\bar{a}$ and $\bar{\imath}$ in this manuscript, I opt for padmākșịn. 
I venerate the beloved husband of Rati, the beautiful Mind-born [God Kāmadeva]. He carries a bow and arrows of flowers and his complexion resembles the petals of Dhak. [Again,] I approach the beloved husband of Priti, bent round (vesțitam) like the full moon, ${ }^{26}$ [serving as] the base for the ring of goddesses, in order to draw the Śricakra for the sake of prosperity.

cintāratnobhayakarāś candrottamsā̄s trilocanāh | aṇimādimahāsiddhìr aruṇāh siddhaye śraye $\|\mathbf{1 2}\|$

a. ${ }^{\circ}$ karāś] em.; ${ }^{\circ}$ karā Ms. c. aṇimāō] em.; animāo Ms.

I take refuge with the goddesses of becoming minute (anima $\bar{a})$ and other great accomplishments (mahäsiddhis) for the sake of success. They hold wish-fulfilling jewels in both hands. They are moon-crested, three-eyed, and red in complexion.

vaṃsídalaśyāmalāingịh kapālotpaladhāriṇịh |

brahmānnyādīr bhaje mātṛ̂r bandhūkarucirāmbarāh ||13\|

c. ${ }^{\circ}$ ṇyādīr bhaje mātṛ̂r] em.; ${ }^{\circ}$ ṇyādir bhaje māntar Ms.

I revere Brahmānī and the other mother-goddesses. They carry a skullbowl and red lily in their hands, their bodies are dark-colored like the leaves of bamboo, and they are clad in lovely [red] clothes resembling bandhūka flowers.

dāntāḥ pāsáānkuśadharāḥ svasvamudrāvaśoditāh | anugrhnnantu me 'bhișțạ̣ mudrādaśakadevatāh ||14\|

a. dāntāḥ] em.; dantāḥ Ms. $\quad$ b. ${ }^{\circ}$ vaśoditāḥ] em.; ${ }^{\circ}$ vadhoditaḥ Ms. $\quad$ c. ${ }^{\circ}$ gṛhṇantu] em.; ogṛhṇamnta Ms.

May the deities of the ten gestures (mudrās), who [have forms that] are in accordance with the powers of their respective gestures, are mild, and carry a snare and goad, endow me with the object of my desire.

26 It appears that Kāmadeva is bent round in the shape of the moon inside the sixteenpetalled and eight-petalled lotuses, and forms the base for the Śricakra in the form of nested triangles. 
raktāḥ pāsāànkuśadharāḥ kalā nityāḥ kalānidheh | ākarșantu mamābhīștam șodaśākrșțiśaktayah ||15||

b. ${ }^{\circ}$ nidheh] em.; ${ }^{\circ}$ nidhih Ms. c. ākarṣantu] em.; ākarṣanta Ms.

May the sixteen goddesses of attraction, [representing] the perennial constitutive digits (kalā nityāḥ) of Kalānidhi [i.e. the Moon], draw towards me the object of my desire.

aruṇāḥ karuṇāvṛttīr devyāś chāyā ivoditāḥ | anañgaśaktīr aṣțau tāḥ pūjayāmi sudurjayāḥ ||16||

a. aruṇāh] em.; aruṇā Ms. $\quad$ ab. ${ }^{\circ}$ vịttīr devyāś chāyā] em.; ${ }^{\circ}$ vṛtti ddaivyā cchāyā Ms. $\quad$ c. așțau tāḥ] em.; aṣțaustā Ms.

I worship those compassionately-disposed goddesses of red-complexion, the eight powers of the bodiless [love-god Kāmadeva], who have arisen like shadows of the goddess [Nityā Sundarī] and are very difficult to conquer.

sarvasaṃkṣobhaṇīpūrvāh śoṇabāṇadhanurdharāḥ| caturdaśa bhaje śaktīś caturdaśajagannutāh $\|17\|$

a. sarvasam ${ }^{\circ}$ ] em.; sarvasa Ms. b. śoṇa ${ }^{\circ}$ ] em.; śoṇo ${ }^{\circ}$ Ms. $\cdot{ }^{\circ}$ rdharāh $]$ em.; ${ }^{\circ}$ dharāḥ Ms. c. caturdaśa] em.; vantadaśa Ms. • • śaktîso ${ }^{\circ}$ em.; śakti Ms. d. jagannutāḥ] em.; jagantutāḥ Ms.

I venerate those fourteen goddesses, with Sarvasaṃkṣobhanī at the fore, to whom [all] fourteen worlds bow. They carry a bow and arrows made of sugarcane.

śubhā varābhayabhṛto vande viśvakuleśvarị̣ | sarvasiddhipradādyās tā bahirdaśakadevatāh || $18 \|$

a. śubhā] em.; śucā Ms. • ${ }^{\circ}$ bhṛto] em.; ${ }^{\circ}$ bhūto Ms. (unmetrical) c. ${ }^{\circ}$ pradādyās] em.; ${ }^{\circ}$ pradadyās Ms.

I venerate all [ten] Kuleśvarīs, starting with Sarvasampatpradā, the goddesses of the external ring of ten. They are auspicious and display the gestures of boon-giving and safety. 
akṣasrakpustakadharāḥ karpūrarucirākṛtīh |

antardaśakadevīs tāḥ sarvajñādyāḥ samāśraye \|19\|

b. karpūra ${ }^{\circ}$ em.; kappūra ${ }^{\circ}$ Ms. c. antardaśaka ${ }^{\circ}$ em.; $\operatorname{antarddhaśaka~}^{\circ}$ Ms.

I resort to Sarvajñā and other goddesses situated in the internal ring of ten. They carry a rosary and a book [in their hands], and their appearance is charming like camphor.

cāpeșupustakākṣasrakcārupāṇicatuștayāḥ|

raktā vāgiśvarīr vande vaśinyādyașțadevatāḥ ||20||

a. ${ }^{\circ}$ srak $^{\circ}$ ] em.; ${ }^{\circ}$ srakta $^{\circ}$ Ms. (unmetrical) b. ${ }^{\circ}$ catușțayāḥ] em.; ${ }^{\circ}$ cantașțayāḥ Ms. $\quad$ c ${ }^{\circ}$ vāgīśva ${ }^{\circ}$ em.; ${ }^{\circ}$ vāgeśva ${ }^{\circ}$ Ms.

I worship those eight goddesses of speech, Vaśinī and others, whose complexion is red. They carry in their four lovely hands a bow, arrows, a book, and a rosary.

raktā varābhayabhṛtah svarūpāinkitamastakāḥ| catasro me diśantv ājñ̄am iṣvādyāyudhadevatāh ||21||

a. 'obrttaḥ] em.; ${ }^{\circ}$ bhūtah Ms. (unmetrical) b. svarūpāo ${ }^{\circ}$ em.; surūpāo Ms. c. catasro] em.; cartasro Ms. d. iṣvādyāo $\bar{a}^{\circ}$ em.; ișțādyāo Ms.

May the four deities of the weapons [of the Goddess] - the arrows and others-red in complexion, displaying the gestures of generosity and protection, marked on the head by their own respective weapon-forms, grant me permission [for worship of the Goddess].

pāśān்kuśāmrtakapālavarābhayāinkair

hastaiś caturbhir abhirāmadṛ́āanunāñḡ |

koṇāgragā trinayanā tarunenducū

kāmeśvarì mama dadātu samastakāmān $\|22\|$

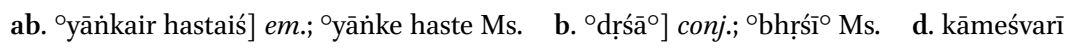
mama dadātu] em.; kāmaśvarī mama dadānta Ms.

May the goddess Kāmeśvarī, who dwells at the front angle [of the central triangle], give me all objects of my desire. She is three-eyed, her eyes are beautiful and her limbs are ruddy. She has the crescent moon on her crest. 
She looks beautiful with her four hands marked with a snare together with a goad, a plate with the nectar of immortality, the gesture of boon-giving, and the gesture of safety.

\section{bālaprabālarucirā karașațkasakta-}

cāpeșupāśaśrnipālakamātulungā |

vajreśvarī prathitadakșinakoṇavāsā

vajrojjvalā vidiśatām mama vāñ̃chitāni ||23\|

a. ${ }^{\circ}$ sakta $^{\circ}$ ] conj.; ${ }^{\circ}$ saddhi $^{\circ}$ Ms. $\quad$ b. ${ }^{\circ}$ mātulungā] em.; ${ }^{\circ}$ māntalungā Ms. $\quad$ d. dadātu] em.; dadānta Ms.

May the goddess Vajreśvarī give me all objects of my desire. She is known to have her abode at the right corner [of the central triangle]. She is resplendent like a thunderbolt, beautiful like fresh coral, and has a bow, arrows, a snare, a hook, a shield, and a mätulunga fruit attached to her six arms.

tryakșā śaśäṅkarucirā śritavāmakoṇā

pāśān்uśekșugunapustakaśastrahastā |

udbhāvayatv aniśam adbhutabhūriśaktir

bhāgyaśriyam bhagavatī bhagamālinī me ||24\|

a. ${ }^{\circ}$ vāmakonāa em.; ${ }^{\circ}$ vāmako Ms. (unmetrical) c. ${ }^{\circ}$ adbhutabhūriśaktir] em.; ${ }^{\circ}$ adbhṛtabhūriśakti Ms. c. bhagavatī] em.; bhagavatā Ms.

May the three-eyed goddess Bhagamālinī give the glory of good fortune. She possesses abundant miraculous power and is as lovely as the moon. She is stationed in the left corner [of the central triangle] and holds in the row of her arms a snare, a goad, a sugarcane, ropes, a book, and a sword.

sūryenduvahnimayabhāsurapīṭarohām

svacchām gṛhìtaśrnipāsáaśareșucāpām |

bālendumaulim alakāgralalāmanetrām

nityām namāmi satatam mahanīyamūrtim $\|25\|$

a. ${ }^{\circ}$ rohāṃ] em.; ${ }^{\circ}$ rohaṃ Ms. $\quad$ b. svacchāṃ] em.; svacchā Ms. $\quad{ }^{\circ}$ cāpām] em.; ${ }^{\circ}$ cāpam Ms. cd. satatam mahanīya ${ }^{\circ}$ ] conj.; mahanīya ${ }^{\circ}$ Ms. (unmetrical)

I uninterruptedly bow to Nityā who has a form worthy of worship. She has ascended the shining throne made of the sun, moon, and fire. She holds 
in her hands a hook, a snare, arrows, and a bow, and carries the crescent moon on her crest. She is pure and clean, and her eyes, adorned with the tips of the locks of hair, are very beautiful.

sindūrasundaratanum tanumadhyabhāgām

kāntyāśrayām kalabhavatkucakumbhanamrām |

candrānanām calakurañganibhāyatākșām

mandasmitām madanamañgalavaijayantīm $\|26\|$

a. ${ }^{\circ}$ tanuṃ] em.; ${ }^{\circ}$ tanu Ms. b. kāntyāśrayāṃ kalabhavatkuca $\left.{ }^{\circ}\right]$ conj.; kāntiśrayaḥ kulabhavatkaca ${ }^{\circ}$ Ms. d. ${ }^{\circ}$ vaijayantīm] em.; ${ }^{\circ}$ vejayantīm Ms.

Her body is beautiful and bears the hue of vermillion. Its middle part is slim, [and] she is the repository of beauty. She is slightly bent like a young elephant because of her pitcher-like breasts, resembling the temples of a young elephant. Her eyes are moving and wide like those of a deer. She is moon-faced, her smiles are gentle, and she serves as the felicitous banner of the Love-god.

koțīinịim kațakakuṇdalahāravalli-

kāñcīkalāpamaṇinūpuramaṇ̣̂itāingìm |

bandhūkabandhuvasanām bahalānurāgām

kāśmìracandanasamullasitāingarāgām $\|27\|$

a. ${ }^{\circ}$ riṇīm kațaka ${ }^{\circ}$ conj.; ${ }^{\circ}$ riṇī kața ${ }^{\circ}$ Ms. (unmetrical) $\quad$ • ${ }^{\circ}$ vallīo] conj.; ${ }^{\circ}$ vallīṃ Ms. $\quad$ b. $\left.{ }^{\circ} \mathrm{kalāpa}^{\circ}\right]$ em.; ${ }^{\circ}$ kālāpa ${ }^{\circ} \mathrm{Ms}$. c. ${ }^{\circ}$ nurāgāṃ] em.; ${ }^{\circ}$ nurāgā Ms.

She has braided hair. Her limbs are adorned with bracelets, earrings, necklaces, twining laces, girdles, jewels, and anklets. Her clothes resemble Bandhūka flowers. She is full of affection, and the hue of her body is brightened up with saffron and sandal paste.

muktāvitānamahite maṇiviștarāgre

paryañkaparșarucire surasopaviștām |

paryainkapañkajamukhị̄n dhutacāmarālām

hāse vilanghitalasadvadanāravindìm $\|28\|$

b. paryañkaparșa ${ }^{\circ}$ em.; paryañkaparya ${ }^{\circ}$ Ms. • suraso] em.; suvaso ${ }^{\circ}$ Ms. $\quad$ c. ${ }^{\circ}$ mukhīṃ dhutacāmarālị̣̄] em.; 'mukhī dhutacāmarālā Ms. d. hāse] em.; hasi Ms. (unmetrical) 
She is elegantly seated on a lofty couch studded with jewels, furnished with seats (paryaikka) and pillows (parșa), and decorated with a canopy of pearls. Her face is a fully developed lotus. She has a row of chowries being shaken around her, and her beaming lotus-face surpasses beautiful lotuses.

ārādhanamravibudhendrabudheśavrnda-

sìmantaratnarucirañjitapādapịthām |

loladviśálanayanām calakelik!̣ta-

svārājyavaiśravanatādivarapradānām $\|29\|$

a. ${ }^{\circ}$ budheśavrnnda ${ }^{\circ}$ em.; ${ }^{\circ}$ buddhasamuda ${ }^{\circ}$ Ms. (unmetrical) d. ${ }^{\circ}$ klpta $^{\circ}$ e em.; ${ }^{\circ}$ klupta ${ }^{\circ}$ Ms.

• ${ }^{\circ}$ vaiśravaṇa ${ }^{\circ}$ ] em.; ${ }^{\circ}$ vaiśramaṇa ${ }^{\circ}$ Ms. • ${ }^{\circ}$ pradānām] Ms ${ }^{p c}$, ${ }^{\circ}$ pradānaṃ $\mathrm{Ms}^{\mathrm{ac}}$

Her foot-rest is illuminated by the rays of jewels on the forehead of the king of gods and other gods as they bow in devotion [to her feet]. She has roving, wide eyes, and she bestows as boons the sovereignty [of Indra] and status [equal to] Vaiśravana, lord of riches, and still more, which she creates in fleeting acts of amusement.

ānandasāndraparamodyamadīpyamāna-

svacchandasaṃsphuradamandataraprakāśäm |

devị̄n dayārdrahṛdayāṃ hṛdayaṃ rahasyam

śrīsundarīn śivakarīm śaraṇaṃ śrayāmi $\|30\|$

a. ${ }^{\circ}$ paramodyama ${ }^{\circ}$ em.; ${ }^{\circ}$ paramedyama ${ }^{\circ}$ Ms. $\quad$ b. ${ }^{\circ}$ samsphura $\left.^{\circ}\right]$ em.; ${ }^{\circ}$ sasphura ${ }^{\circ}$ Ms. c. devīm ] em.; devī Ms. • hṛdayam rahasyam] em.; hṛdaya rahasya Ms.

I seek refuge with the glorious goddess Sundarī, the benefactress of prosperity, the secret heart, whose heart is soaked with compassion. She is blazing with an utmost tenacity steeped in joy, and consequently beaming with plenteous light that shimmers spontaneously.

tvāṃ devi devamahișìm avibhāgabhogām

bhogāpavargaphaladām bhuvaneśi dhārām |

śaivādhibhūmyavadhișadgunitātmașațka-

vaicitryacitraracanodbhavabhāvamārgām $\|31\|$

ādhāravāriruhașațkavilāsasaumye

saușumṇavartmani sudhāmśurasān śravantīm | 
ānanditatribhuvanām aruṇāruṇāngīm

vande 'ham ādyamahasam manasāpi vācā || 32||

31b. dhārām] conj.; dhārāḥ Ms. $\quad$ 31c. śaivādhibhūo] conj.; śivādhibhūo Ms. $\quad$ 31d. vaicitrya $^{\circ}$ ] em.; vecitra ${ }^{\circ}$ Ms. • • ${ }^{\circ}$ bhāvamārgām] conj.; ${ }^{\circ}$ bhivamārggah Ms. $3^{2}$ b. saușumṇa ${ }^{\circ}$ em.; sauṣyamna ${ }^{\circ}$ Ms. $\quad 3^{2 c}$. ānanditatri $\left.{ }^{\circ}\right]$ em.; ānanditastri ${ }^{\circ}$ Ms. $\quad$ • $^{\circ}$ ruṇāngīṃ] em.; ${ }^{\circ}$ ruṇāngī Ms. 32d. vande 'ham ādya ${ }^{\circ}$ conj.; $\mathrm{m}$ ādya ${ }^{\circ}$ Ms. (unmetrical) • vācā] em.; vāpi Ms.

$\mathrm{O}$ goddess, I praise you with mind and speech. Your greatness is primordial. Your limbs are slightly ruddy like the morning sun, and you have made the triple world happy. You are the bride of the god [i.e., Śiva], and possess a body inseparable [from his]. You bestow worldly enjoyment and also liberation from [the world]. You are the stream [of consciousness or immortality] (dhāra $\bar{a}),{ }^{27} \mathrm{O}$ ruler of worlds. Dwelling originally in the abode of Śiva, you multiply yourself sixfold and prepare the path of existence where you nurture wonderful and manifold creation with your own six forms. You shed moonlight on the path of Susumṇā that is charming due to the beautiful appearance of the six lotuses serving as [your] bases.

\section{ekaikavaty api navāsi daśāsi devi}

bhūyo daśāsi punar eva caturdaśāsi |

ittham trikādhikadaśadvitayadvayāñke

śaktyarṇave vasasi śarmakarī kavīnām $\|33\|$

a. ekaikavaty api] conj.; ekekavaty asi Ms. c. ittham trikāo] conj.; itthan nrikāo Ms. • ${ }^{\circ}$ dvayānnke] em.; ${ }^{\circ}$ dvayāke Ms. d. śaktya ${ }^{\circ}$ ] conj.; śaktyāo Ms. • kavīnāṃ] em.; kavānāṃś Ms.

O goddess, though you are one and simple, ${ }^{28}$ you are [also] nine, ${ }^{29}$ you are ten, you are again ten, and again you are fourteen. Thus you, the benefactor of poets, dwell in the sea of Śaktis marked with forty-three triangles.

27 These two verses depict the goddess as the stream of consciousness or immortality in the human body, known widely as Kunḍalinī, originating from the brahmarandhra, the abode of Śiva, flowing through various channels and reaching to the six bases. It is in this light that these verses should be read.

28 I have conjectured api in place of asi to provide a concessive tone. Perhaps this is not even necessary. In any case, on her own the goddess is singular and unembellished, but the poet appears to imply that all goddesses in different retinues of the Śrīcakra are her projections.

29 The central triangle and the immediately following retinue of eight triangles are obviously counted together as nine. 


\section{lakșmìm parāṃ prakrtim atrajagaty aśeșam \\ ekātapatradharacāmaracārucihnām | \\ mātar maheśvariyaśaskrtam ādyaśaktim \\ prāhuh parāparadrśam parameśvari tvām $\|34\|$}

a. lakșmīṃ] em.; lakṣmīḥ Ms. • • aśeșam] conj.; aśișam Ms. a. ${ }^{\circ}$ cihnām] em.; ${ }^{\circ}$ cihnāḥ Ms. c. mātar mahe ${ }^{\circ}$ em.; māta'rmmahe ${ }^{\circ}$ Ms.

O Mother! Great Goddess! Supreme Goddess! People proclaim you Lakșmī, Parā Prakṛti, ${ }^{30}$ who has chowries as lovely distinctive marks and who bears a sole [royal] parasol covering the entire world. They proclaim you as the conferer of fame, the primordial power, and the supervisor of both higher and lower realms.

śrīs tvam śriyas tvayi giras tvayi gīs tvam ājñā

dhis tvam dhiyas tvayi puras tvayi pūs tvam ādyā |

śaktịn parā tvam asi śaktiguñās tavaite

kim vistarena nanu sarvam idạ̣ tvam eva $\|35\|$

a. ājñā] em.; ājnā Ms. b. pūs tvam] conj;; pus tam Ms. c. tavaite] em.; tavete Ms.

You are the goddess of prosperity, and prosperities depend on you. You are the goddess of speech, and authority and words depend on you. You are the goddess of wisdom, and wise ideas depend on you. You are the foremost fortress, and towns depend on you. You are the primordial power, and yours are all the properties of power. What is the use of any further explanation: this entire world is nothing but you.

tvām āvadanti munayas tamaso nihantrīm

āhlādinị̣̄ smṛtimatām amṛtạ̣ duhānāṃ |

nityoditām anuditāstamayaprasañgām

antaścarīm śaśikalām akalañkaśan்kām $\|36\|$

a. tamaso nihantrīm] em.; tamasā nihandrīm Ms. d. antaścarīṃ] conj.; mantaścarī Ms.

$30 \quad$ A number of older texts, including the Śāmkarabhāsya (on Brahmasūtra 2.2.42), state that the Pāñcarātrikas identify Vāsudeva as Parā Prakṛti, the supreme cause (for a discussion on Vāsudeva as Parā Prakṛti, see Watson, Goodall and Sharma 2013, 30-31, 241-246). However, according to a verse attributed to the Skandapurāna and cited in the Bhagavatsandarbha of Jīva Gosvāmin, Śrī is Parā Prakṛti, the consciousness associated with Viṣnu (śrīh parā prakrtih proktā cetanā viṣnusaṃśrayā $\mid ;$ Bhagavatsandarbha, p. 278). It is possible that our 
Sages address you as the destroyer of darkness, the bestower of delight, yielding the immortal nectar to all those who remember you. They address you as the ever-risen one with no possibility of rising and setting, as the underlying digit of the moon ${ }^{31}$ never suspected to have a stain.

tvattejasā tapati devi patir dinānām

āpyāyayaty api karair amṛtạ̣ himāṃsúuh |

prānāās tapanta iha vāyuvaśāc charīre

tvām antarena na hi kasya cana pravrttị || $37 \|$

a. tvattejasā] em.; tvattojasā Ms. • patir di $^{\circ}$ ] em.; pati ddi ${ }^{\circ}$ Ms. b. āpyāyayaty] em.; āpyā-

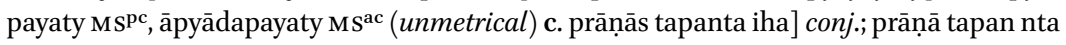
iti Ms. • charīre] em.; charāre Ms. d. cana pravṛttiḥ] em.; jana pravṛrttiḥ Ms.

O Goddess! With your energy the sun burns, the moon expands the immortal essence with his beams, and here in our body the vital functions glimmer under the control of the vital air. For, without you none can function at all.

\section{[ lokāś caturdaśa mahendramukhāś ca devāh mūrtitrayam munigaṇāś ca vasișthamukhyāh | sadyo bhavanti na bhavanti samastamūrter unmïlanena tava devi nimïlanena $\mid$ 37a $\|]^{32}$}

poet is telling us about two different identifications: Nityā as Lakṣmī, the consort of Viṣnu, and Nityā as Parā Prakṛti Vāsudeva, the supreme cause of both sentient and insentient beings.

31 The underlying digit of the moon (antaścarī śaśikalā) in all likelihood is the sixteen innermost digit beyond the waning and waxing process.

The late Pundit Vraja Vallabha Dwivedi $(1985,45)$ presents this verse in his preface (originally written in 1968) to the Nityāṣodaśikārnava as cited in the Arunāmodin̄ commentary of the Saundaryalaharī and attributed to the Kämasiddhistotra of Vatsarāja (cf. Śāstrī 1957, 221), and suggests that it should be located in the Nepalese palm-leaf manuscript of the text (the same manuscript I am editing now). However, in 1983 in the Luptāgamasamgraha, a collection of citations from lost Āgamic texts he prepared, he writes that the verse is not found in the palm-leaf manuscript and so must come from a different text (cf. Dwivedi 1983, 25). I think Dwivedi arrived at this conclusion without reading the implied name of the stuti. The author of the Arunāmodinī writes that it is a verse from the Kämasiddhistotra of Vatsarāja, and the same name is alluded to in the last verse of our text. I conclude that the verse therefore belongs to this text even though it is not found in the palm-leaf manuscript. I assume that it was dropped in the process of transmission. It is thus just possible that there are still a few more verses missing from the latter part of the stuti. 
The fourteen worlds, all gods headed by Mahendra, the three embodiments [of the ultimate reality], and also the groups of sages headed by Vasisțha, come into existence or cease to exist, $O$ goddess, by the opening and closing of your eyes, because you embody all.

vedā vibhinnagatayo viduṣah svatantrās

tantrāni mantranivahā mahitaprabhāvāḥ |

bhāvā vibhaktivișayāh kavigumphanāś ca

mātah param parịnamanti tavāyutāṃśāt $\|38\|$

b. prabhāvāḥ] em.; prabhāvoḥ Ms. c. ca] em.; va Ms. d. ํ̣amanti] em.; ${ }^{\circ}$ namanti Ms.

The Vedas, independent scholars of different capabilities, the Tantras, the collection of mantras with celebrated powers, and thoughts and feelings concerning syntax and grammar (vibhaktivișaya) and poetic compositions, all these, $\mathrm{O}$ mother, evolve to excellence from a millionth part of you.

yas te vibhūni paramapravilambitātmā

buddhyā pramitsati pumān purușaḥ pramāyāḥ |

samssprśyati ${ }^{33}$ sphuțam asau bhuvane pațīyān

cchāyām svakīyaśirasaḥ svapadakrameṇa $\|39\|$

b. pramitsati pumān] em.; pramicchati pumāna Ms. (unmetrical) b. svapadakrameṇa] em.; svayadakramena Ms.

Any person who is hanging on to the ultimate [reality of yours] (paramapravilambitātma $\bar{a}$ ) and wishes to perceive and measure your proportions $(v i b h \bar{u} n i)^{34}$ with his [limited] mind, that man of perception (pramāyāh purusah) smarter [than everyone] in this world evidently touches the shadow of his own head in a series of his own footsteps. ${ }^{35}$

abhyarcya devi bhavatīm vibhavāmi bhūmim

āmnāyadarśitapathena yathā-kathañcit |

33 Our poet is using the root sprś as if it belongs to the fourth class. We cannot emend it to samsprśati, because that would be unmetrical.

34 The word vibhu is treated here clearly as a noun.

35 This reminds me of a verse attributed to the now lost Trikahrdaya and cited by Kșemarāja in his commentaries (e.g., Śivasūtravimarśin̄̄, p. 9): svapadā svaśiraśchāyāmyadval lañghitum īhate | pādoddeśe śiro na syāt tatheyam baindavī kalā ||. 
vācoratair atibhavābhidhakanyakāyā

vāllabhyavartmani janair na viganyate kah $\| 40$

c. atibhavābhidha ${ }^{\circ}$ conj.; adhibhavāvidha ${ }^{\circ}$ Ms.

d. ${ }^{\circ}$ vartmani janair na] em.; ${ }^{\circ}$ vatmani janai nna Ms.

O goddess! Having worshipped you I somehow manage to govern [my] land following the path dictated by the scriptures. [But] who among the people on the path of winning the love of the young lady called Atibhavā-the one who has transcended the world—is not disrepected by those people who are engaged in gossip?

sā tvam samāhitadhiyo hṛdayañgamāsi

gāyantigauri madhurās tava kìrtigāthāḥ |

hālāsugandhiharicandanavātikīàsu

vidyādharā vibudhasindhutațasthalīṣu || $41 \|$

a. sā tvaṃ samāhitadhiyā] conj.; sā ddhaṃ samāhitadhiyo Ms.

O goddess! You enter the heart of a man whose mind is composed. Sweet ballads of your renown, $\mathrm{O}$ Gaurī, the vidyädharas sing in the groves of Haricandana trees that emit the sweet fragrance of liquor on the banks of the heavenly river.

devi tvadīyamahasā mahitā mahānto

bhālekșaṇạh śaśibhṛto bhujagendrabhūṣāḥ|

siddhāntasiddhiparamārthavidhiprasiddhāh

siddhāḥ sudhāmśsuvadane śivatāọ vrajanti $\left\|_{42}\right\|$

a. tvadīya ${ }^{\circ}$ em.; tadīya ${ }^{\circ}$ Ms. • mahānto] em.; mahāmbho Ms. b. bhāle ${ }^{\circ}$ em.; bhālo ${ }^{\circ}$ Ms.

- `bhūṣāḥ] em.; ' bhūṣaḥ Ms. d. sudhāṃśuvadane śivatāṃ] em.; sudhāśuvadane śivantā Ms. (unmetrical)

O goddess, those great people who are honoured with your greatness achieve Śivahood as they attain perfection. They are the people who have attained perfection following the regimen prescribed in the [system of] Siddhānta for the purpose of supernatural powers as well the ultimate goal [of liberation]. O moon-faced [goddess, they] bear [the characteristics of Siva]: the third-eye on the forehead, the moon on the head, and the ornaments of serpents. 


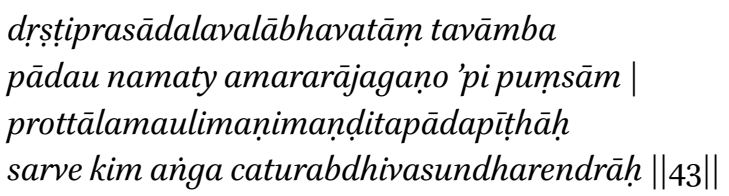

a. 'lavalābhavatāṃ] em.; 'lavālābhavatāṃ Ms. (unmetrical) prottvālamoli ${ }^{\circ}$ Ms.

O mother! Even the kings of gods bow to the feet of those men who have acquired a drop of the grace of seeing you. Kings of all the rich lands extending to the four oceans [bow to them] all the more, illuminating their footrests with the studded jewels of their elevated crowns.

tvām kledanìti kulakuṇdalinīti keti

nityeti nütir iti naur iti nāviketi |

vidyeti samvid iti viśvamayity umeti

kāmeśvarîti kamaleti vadanti santaḥ ||44\|

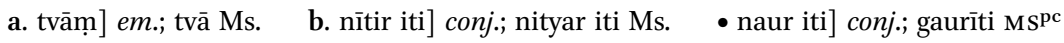
(unmetrical), gaur iti $\mathrm{MS}^{\mathrm{ac}}$ d. vadanti] em.; vadānta Ms. • santah] bottoms damaged

Mindful men call you Kledanī, Kulakuṇ̣alinī, Kā, Nityā, Nīti, Nau, ${ }^{36}$ Nāvikā, Vidyā, Saṃvid, Vīśvamayī, Umā, Kāmeśvarīi, ${ }^{37}$ and Kamalā.

ekām anuttarakalām kulanāthakāntām

bālām atulyamahasaṃ bahumañgalā d̆hyām |

ānandamūrtim akhilärthavilāsahetum

ādyāṃ smarāmy aviratam paramārthavidyām $\|45\|$

a. ${ }^{\circ}$ kalāṃ] em.; ${ }^{\circ}$ kalā Ms. b. bālām atulya ${ }^{\circ}$ em.; bālātulya ${ }^{\circ}$ Ms. (unmetrical) • • bahumañgalāḍhyām] conj:; ' bahu[pa]lāạhyā Mspc, obahulāḍhyā Ms ${ }^{\text {ac }}$ (both unmetrical) cd. ' hetum ādyāṃº ${ }^{\circ}$ em.; ${ }^{\circ}$ hetummm ādyāṃ Ms.

$3^{6} \quad$ The original reading of the manuscript gauriti is unmetrical. The scribe has corrected it to gaur iti which is just possible, but I conjecture naur iti because of the following word nāviketi. Thus, also, the syllabic rhyme of the line is restored.

37 Thus, there are three deities in this tradition who can be called by this name: the chief goddess Nityā, one of the goddesses in the central triangle, and one of the goddesses of speech in the retinue of eight triangles. 
I uninterruptedly remember [you], the Vidyā leading to the ultimate wellbeing, embodiment of bliss, the cause of the extension of all prosperities. [You are] the primordial one, the insurpassable Kalā. You are Bālā, the beloved of Kulanātha (namely, Śiva). [Your] glory is incomparable, and you are filled with many felicities.

yaḥ kāmasiddhim atimañgalakāmadhenum

kāmeśvarīstutim imām paṭhati pratītạ |

kāntyā śriyā kavitayā gunasampadā ca

so 'yam svayam vivrta eva kimu priyābhih $\|46\|$

a. kāmasiddhim atio ${ }^{\circ}$ em.; kāmasiddhir iti Mspc, kāmaḥsiddhir iti Msªc (unmetrical)

One who recites this eulogy of Kāmeśvarī called Kāmasiddhi, which serves as a very auspicious wish-fullfilling cow, placing trust [in her], is specially chosen (vivrta) by [the goddesses of] Beauty, Prosperity, Eloquence, and Treasury of Qualities. So, what would he do with any [other] lovers?

iti śrīmahārājādhirājavidyādharacakravartivatsarājaviracitā śrīvāmakeśvarīstutị̣ samāptā $\|\otimes\|$

Here ends the Vāmakeśvarīstuti composed by Vatsarāja, the king of great kings, the sovereign among the vidyädharas.

\section{References}

\section{Primary Sources}

Adhikaranasāāāvalī of Vedāntadeśika. Kanchi P.B. Annangaradharyar, ed. Vedāntadeśikagranthamālā. Madras: Sannidhi Press, 1940.

Aruṇāmodinī. See Śāstrī 1957.

Nišvāsaguhya. The Guhyasūtra of the Niśvāsatattvasaṃhitā. NAK MS 1-227. (The Guhyasūtra starts on folio 41). NGM P P Reel No.A 41/14. Palm-leaf, Folios 117, early Nepalese (Kuṭilā) script. There are two apographs available, both in Devanagari and on paper: NAK MS 5-2401, NG MPP Reel No. A 159/18, and Welcome Institute for the History of medicine, London, Sanskrit MS I.33. The verse and chapter numeration used in this paper is that of Dominic Goodall's edition in progress.

Tantrāloka. Mukund Ram Shastri, ed. The Tanträloka of Abhinavagupta With commentary of Räjānaka Jayaratha, vol. 1. Kashmir Series of Texts and Studies, no. 23. Śrīnagara: 1918. Reprint, Delhi: Motilal Banarsidass, 1987. 
Brahmāṇdapurāṇa. J.L. Shastri, ed. Delhi: Motilal Banarsidass, 1973.

Bhagavatsandarbha of Jīva Gosvāmin. Haridāsa Śāstrī, ed. Bhāgavatasandarbhe dvitīyah śrībhagavatsandarbhaḥ. Vṛndāvana: Gadādhara Gaurahari Press, 1984.

Vāmakeśvaratantra. Vraja Vallabha Dwivedi, ed. Nityāṣoḍaśikārṇava with Two Commentaries Rjuvimalā by Śivānanda \& Artharatnāvalī by Vidyānanda. Second Edition. Benares: Sampūrṇānanda Sanskrit University, 1985.

Śivasūtravimarśinī. J.C. Chatterji, ed. The Śiva Sūtra Vimarshinī, being the Sūtras of Vasu Gupta with the Commentary called Vimarshinī by Kshemarāja. Kashmir Series of Texts and Studies, no. 1. Bombay: Nirnaya Sagar Press, 1911.

\section{Secondary Sources}

Bautze-Picron, Claudine 2002. "Nidhis' and Other Images of Richness and Fertility in Ajanțā." East and West $5^{2}$ (1): 225-284.

Dalal, Chimanlal. 1918. Kālañjarādhipatiparamarddidevāmātyakavivatsarājapraṇītarūpakașaț[k]am. A Collection of Six Dramas of Vatsarāja. Gaekwad Oriental Series, no. 8. Baroda: Central Library.

Dwivedi, Vraja Vallabha, ed. 1983. Luptāgamasaṃgraha, part II. Yogatantra Granthamālā, no. 10. Benares: Sampūrṇānanda Sanskrit University.

Dwivedi, Vraja Vallabha. 1985. See Vāmakeśvaratantra.

Golovkova, Anna. 2012. “Śrīvidyā." In Brill's Encyclopedia of Hinduism, vol. IV, edited by K.A. Jacobson, 815-822. Leiden: Brill.

Goodall, Dominic, Nibedita Rout, R. Sathyanarayanan, S.A.S. Sarma, T. Ganesan, and S. Sambandhaśivācārya. 2005. The Pañcāvaraṇastava of Aghoraśiva: A twelfth-century South Indian Prescription for the Visualisation of Sadāsiva and his Retinue. Collection Indologie, no. 102. Pondicherry: Institut Français d' Indologie/École française d'Extrême-Orient.

Goodall, Dominic, in collaboration with Alexis Sanderson and Harunaga Isaacson with contributions of Nirajan Kafle, Diwakar Acharya and others. 2015. The Niśvāsatattvasaṃhitā. The Earliest Surviving Śaiva Tantra. Volume 1. A Critical Edition and Annotated Translation of the Mūlasūtra, Uttarasūtra and Nayasūtra. Collection Indologie, no. 128 (Early Tantra Series, no. 1). Pondicherry: Institut Français d' Indologie/École française d' Extrême-Orient/Universität Hamburg.

Paranavitana, S. 1955. "Śaṃkha and Padma." Artibus Asiae 18 (2): 121-127.

Sanderson, Alexis. 2009. "The Śaiva Age: An Explanation of the Rise and Dominance of Śaivism during the Early Medieval Period." In Genesis and Development of Tantrism, edited by Shingo Einoo, 41-349. Tokyo: Institute of Oriental Culture, University of Tokyo.

Śāstrī, Anantakṛṣna. 1957. Saundaryalaharī of Śrī Śaṃkarācārya with Commentaries: Saubhāgyavardhan̄ of Kaivalyāśrama, Lakșmīdharā of Lakṣmīdharācārya, Aruñāmodinī of Kāmeśvarasūrin. Edition, English Translation and Notes. Madras: Ganesh $\&$ Co. 
Sinopoli, Carla M. 2010. "Echoes of Empire: Vijayanagara and Historical Memory, Vijayanagara as Historical Memory." In Contemporary Archaeology in Theory: The New Pragmatism, edited by Robert W. Preucel and Stephen A. Mrozowski, 17-33. New York: John Wiley \& Sons.

Sircar, Dines Chandra. 1983. Select Inscriptions bearing on Indian History and Civilization From the Sixth to the Eighteenth Century A.D. Volume II. Delhi: Motilal Banarsidass. Watson, Alex, Dominic Goodall, and S.L.P. Anjaneya Sarma. 2013. An Inquiry Into the Nature of Liberation. Bhaț̣ā Rāmakanțha's Paramokșakārikāvrtti, a Commentary on Sadyojyotih's Refutation of Twenty Conceptions of the Liberated State (moksa). Collection Indologie, no. 122. Pondicherry: Institut Français d'Indologie/École française d'Extrême-Orient. 